\title{
Appreciative, Creative, and Innovative Literary Learning in University: Literary History as a Model
}

\author{
Didi Suhendi \\ Universitas Sriwijaya, \\ Palembang, Indonesia \\ didisuhendioke@yahoo.com
}

\begin{abstract}
This paper was ideas to response problems of the teaching of literature at university which has been more focused on literary theory. The literary work was as if the artifacts 'inanimate' that do not provide any benefits so that its presence was not involved in the study of literature. Therefore, the following ideas should be emphasized in teaching literature at university. First, the learning of literature should be done in a team/group (team-work). Second, the study of literature should include three aspects, namely cognitive, emotive and evaluative aspects. Third, the learning of literature should involve literary works. The students' task was to confront the concepts of literature and literary works. They are, for example, find the characteristics of each period works of literature on the facts/data contained in literary works in accordance with its period. Fourth, within the framework of learning in creative and innovative literature, students are required to do the work and evaluation that sustains the ability of literary appreciation. For example, on an individual basis, students analyze the development of aesthetic elements or differently nonaesthetic and students are required to make a synopsis of the literary works of the period Balai Pustaka until the period of the 2000s. Meanwhile, the evaluation given is not emphasized in the realm of memory and comprehension but directed at the realm of application and evaluation.
\end{abstract}

Keywords: creative and innovative literary learning, literary history, period of literature

\section{I.INTRODUCTION}

Not a few people, both ordinary people, and academics, who think that literary works are empty imaginations, daydreams, and wishful thinking that do not bring any benefit. Literary works are no more than dead objects " artifact" that is used only to fill the void of activity. The assumption is based on the initial assumption that literary work is a product of imagination, the fantasy of authors who "escape from the reality of life". Therefore, literary subjects have less desirable among the students.

In a sociological perspective, literary works are not considered merely 'dead objects', but are seen as a social-cultural product that cannot be released with the element of its genesis, the society of its creator. In essence, literary work is a reflection of the life of a society that is created in such a way by the author through the mediation of the universe of characters and characterizations, setting, link of events, the point of view and so on. In other words, all the "circumstances" of life in the society of the author are recorded intensely into a miniature of words. It is clear here that sociological issues in society are recorded in literary works. That is why [1] states that literature is not born in a cultural vacuum. The context of a society that is the background of the creation is closely related to the context of the society in literary works.

What is stated above is, of course, not about the works of pop literature or literary works of "pics" (two terms commonly used by some scholars to refer to less quality work), but rather referring to works of great quality or works and immortal? By borrowing the term Roman Ingarden, works of great and eternal are works that have the stratum of norms to the metaphysical/religious layer (a stratum of metaphysics), which is a work that can evoke contemplation of life to its readers [2] It is these works that not only provide entertainment, fun but also provide great benefits or usefulness to their readers. Horace in [3] mentions the above with the term dulce et utile.

In one of their books, [4 states that a qualified literary work is a work capable of interpreting life and giving renewal. Literature does not merely record and record the lives of its people, but also able to interpret human life by providing new views on all matters of human problems. Great literary works (quality) provide an experience as well as appreciate the reader about life knowledge. In his literary work, the knowledge he acquires is alive because only through literary mediation, knowledge, and experience about life are presented in depth. If in other disciplines, knowledge is obtained through reasoning, in the literary work of knowledge gained through reasoning and appreciation. That is why literary learning should involve cognitive, emotive, and at the same time evaluative aspects.

\section{APPRECIATIVE, CREATIVE, AND INNOVATIVE LITERATURE LEARNING}

There are three keywords that need to be explained in terms of the above, namely the word appreciative, creative, and innovative. The three words are categorized adjective that each taken from noun appreciation, creation, and innovation. In English, the word appreciation corresponds to the appreciation of meaningful appreciation, understanding, and knowledge [5]. In the Great Indonesian Dictionary (KBBI), the word appreciation means (a) an awareness of values, art, and culture; (B) an assessment (reward) of something [6]. Meanwhile, in [6], the word creations (synonymous with creation in English) mean (a) the result of creativity, imagination; (B) the result of the creation of the mind or the intellect of the human mind. Furthermore, in KBBI, the word innovation (meaning in English innovation) means (a) the introduction or introduction of new 
things, renewal; (B) new findings that are different from existing or pre-existing ones (ideas, methods, or tools) [6].

Based on the above etymological meanings, appreciative literary learning is a literary learning that gives effect to the reader (learners), that is giving impact to the values of life through the mediation of literary activities (reading, understanding, analyzing, living, evaluating) intently and continuously. Ref. [7] states that the teaching of literary works should at least contribute to four things, namely (1) supporting the language skills (listening, speaking, reading and writing); (2) enhancing cultural knowledge; (3) to develop taste and intention; (4) forming character (learners). Meanwhile, creative learning is more interpreted as learning that is built and created in such a way that learners do literary activities with great pleasure, enjoyment, and comfort. To present such learning, Oemarjati in [7] suggests five stages of activity (1) interrogating, looking at the data in the work (fact-finding); (2) to formulate problems (problem finding); (3) to propose as many ideas as possible, ideas, ideas to be solved; (4) solving problems (solution finding); Plan the implementation (plan of action). On the contrary, innovative learning brings to light the novelty of literacy learning. Literary learning is given differently from the conventional or traditional learning that has been done.

From the exposures presented above, it can be stated here that appreciative, creative, and innovative literary learning has the following characteristics. First, the study of literature must involve three aspects, namely cognitive aspects (knowledge), emotive aspects (feelings), and evaluative aspects (assessment). In the theory of reader response, astonishingly, [8] have proposed seven strategies covering three aspects: engaging (engaging taste), describing, conceiving, explaining, Connecting, interpreting, and judging. These three aspects should be implemented in the learning process, learning tasks, and learning evaluations. Secondly, literary learning should involve students reading literary works. Third, literary learning should utilize multimedia as a means to train sensitivity of taste, intention, and inventiveness. Fourth, literary learning is done in teamwork (cooperation) through discussion/brainstorming. It is not only used to provide knowledge enrichment, but also more than that, learners are trained to practice positive social attitudes, such as cooperation, tolerance, democracy, solidarity, and so on. Fifth, literary learning is done by using many models/methods/strategies instructional techniques. Literary teachers do not rely on one method or learning strategy, for example, but must apply various methods or learning strategies so that literary learning comes in a pleasant atmosphere.

\section{LITERARY HISTORY AS A MODEL IN LITERATURE LEARNING}

\section{A. Course Material Literature History}

Literary history courses are taught in Indonesian Language and Literature Education, FKIP, Sriwijaya University (Unsri) in even semesters, on semester students of the undergraduate program. The weight of this course is 3 credits. In general, the material of this course contains the development of Indonesian literature from the Balai Pustaka period (the 1920s) to the period of the 2000s. This material can be read comprehensively through online because the learning is electronic (e-learning). The purpose of this course is for students to identify the development of Indonesian literature in that year's span. For more details, below is given a table of substance courses Literary History.

TABLE I. LITERATURE HISTORY MATERIALS

\begin{tabular}{|c|l|}
\hline Number & \multicolumn{1}{|c|}{ Substance } \\
\hline 1. & $\begin{array}{l}\text { Understanding History of Letters, Periods, and Literary } \\
\text { Forces }\end{array}$ \\
\hline 2. & $\begin{array}{l}\text { Writing of Conventional Literature History and Literary } \\
\text { Reception }\end{array}$ \\
\hline 3. & $\begin{array}{l}\text { Periodization of Indonesian Literature by Various } \\
\text { Literary Experts }\end{array}$ \\
\hline 4 & $\begin{array}{l}\text { Period Balai Pustaka (History, Characteristics, works } \\
\text { and their authors) }\end{array}$ \\
\hline 5. & $\begin{array}{l}\text { New Poet Period (History, Characteristics, works and } \\
\text { their authors) }\end{array}$ \\
\hline 6. & $\begin{array}{l}\text { Period Force 45 (History, Characteristics, works and } \\
\text { their authors) }\end{array}$ \\
\hline 7. & $\begin{array}{l}\text { Period Generation 66 (History, Characteristics, works } \\
\text { and their authors) }\end{array}$ \\
\hline 8. & $\begin{array}{l}\text { Period Generation 70s (History, Characteristics, works } \\
\text { and their authors) }\end{array}$ \\
\hline 9. & $\begin{array}{l}\text { Period Force 2000s (History, Characteristics, works and } \\
\text { their authors) }\end{array}$ \\
\hline
\end{tabular}

The above material is taught for one semester. The material on points 1 through 5 are taught before the Middle Examination Semester (UTS), while the rest (material points 6 to 10) is taught after UTS. Meanwhile, assignments are given individually and in groups. Individually, learners are tasked with analyzing the development of the aesthetic or extra aesthetic elements of Indonesian novels (from the Balai Pustaka period up to the 2000 s period) synchronically or diachronically. In addition, students are assigned to make a synopsis of 6 different novels. Conversely, in groups, students are assigned to answer questions, identify and discover the characteristics of each period and present it in the form of power points. This task is given at each meeting periodically.

\section{B. Activity Before Learning}

Prior to lectures or first meetings, heterogeneously (based on ability, gender, and regional origin), the students were divided into six groups with the names of the Angkatan Balai Pustaka, the Angkatan Pujangga Baru, the Angkatan 45, the Angkatan 66, the Angkatan 70s and the Angkatan of 2000s. The name is used in accordance with Indonesian literary revelation. It is intended that learners to know and remember the development of Indonesian literature that is classified into rounds or periods. Furthermore, each individual in each group is assigned to read and synopsis a novel in each period. So, every learner should make six novel synopses from different periods. The novels read in each individual must be different from the others. If the number of students in a class of 30 students, the synopsis is collected in one semester is 180 novels. This method is done to "force" students to acquire and love literary works as a form of their appreciation.

In addition to the task of making a synopsis, students are assigned to analyze the development of aesthetic and/or extra esthetic aspects of the novels he or she reads diachronically. Of course, not all novel aesthetic or extracellular aspects are analyzed. Students simply take one or part of the aspects that are 
seen prominently in the novels he read for analysis of its development, such as the development of points of view, characterizations, themes, or ideas or certain ideologies laden with the novel. This task is intended to train students to conduct further research.

\section{Learning Activities}

In the study of literature, the task of learners is "to unite" or to bring the concepts or theories and facts or data that exist in the literary work (novel). Therefore, in the main activities, lecturers do not explain the concepts or learning materials (because the material is complete already available in the form of an online/soft file), but asks, demanding learners to find evidence/data that exist in the literary works. For that, the first step in this activity is a group of learners looking for data in accordance with the theory/concept that already exists. For example, the novels of the Balai Pustaka literature period generally have the following characteristics: (1) the language uses cliches, parables, proverbs, or proverbs; (2) characterizations used by the physical description of the character directly; (3) the theme raised is the conflicts of young people with the elderly and forced marriage. To prove the truth, the team of learners discuss (1) find the language of cliches, parables, proverbs, proverbs in the novel Balai Pustaka; (2) find a physical description in the novel Balai Pustaka; (3) to identify words, phrases, clauses, sentences, and even certain paragraphs that indicate the physical description of the person directly in the novel Balai Pustaka. Of course, each group is required to bring several novels of Balai Pustaka, such as Siti Nurbaya by Merari Siregar, Di Bawah Lindungan Kabah by Hamka, or Salah Asuhan by Abdul Muis. Such things need to be trained to the students because during this literary learning only dwell on the problem of theory. In fact, not a few learners are not told/taught how to find a theme and a mandate, for example. As a prospective teacher, students should be trained for that purpose.

The second step is to ask the group representatives to present their findings through the in-focus screen in the form of power points. Here, the lecturer determines who and what to present, not the leader of the group, by pointing directly or randomly. This is done so that each individual in the group is always responsible for the success of his group. After the group representatives presented the results of their discussion, another group responded. At this point, learners conduct classical discussions. This process continues until all group representatives present. At each meeting, this pattern is not always the case. In subsequent meetings, lecturers can apply different learning models or learning strategies at each meeting. Nevertheless, the principle of learning still has a common thread, the task of learners is to unite the concept with facts/data that exist in the literary work.

The third step is an explanation of the mistaken concepts or wrong examples that the students presented in the previous step. At this stage, the lecturer shows in real those mistakes while pointing out the truth. Through mediation in focus, the lecturer explains the argument in detail and clearly. Learners, in this case, the students, are given the freedom to respond, ask, or even give opinions differ from their lecturers.

\section{After Learning Activities}

In this final activity, there are some things that need to be done by lecturers and students. First, the student must conclude the learning material that has been done. It is important to get the gist of learning according to the learning objectives at each meeting. Second, students and lecturers should always do reflection, especially to find any weaknesses in the learning process that has been going on. The significance of this stage is for continuous improvement at subsequent meetings. Third, students are given further tasks as a form of enrichment of the material they have learned. For example, discover the aesthetic and extra aesthetic characteristics of other novels that he read.

\section{CLOSING}

Based on the above explanation, several points need to be mentioned related to the study of Literary History. First, students are subjects or learning actors who are required to actively find and analyze tasks given in groups. Instead, the lecturer controls the learning and continuously directs the learning to the intended purpose. In other words, the Student-Centered Learning (SCL) learning becomes the main point of departure. Second, literary learning should "involve" literary work. Students are "forced" to interfere with literary works by (a) understanding, identifying, analyzing, finding, linking literary works (cognitive aspects); (B) involves/senses, responds with feelings to events or events experienced by the works (emotive aspect); (C) provide an evaluative response to the work analyzed (evaluative aspect). Third, literary learning not only emphasizes the results or products in the form of papers or value/numbers, more than that the quality of the learning process should also be emphasized. The quality of UTS and UAS values obtained by students is directly correlated with the quality of the learning process. A good process will produce a good product.

\section{REFERENCES}

[1] Teeuw, A. 1984. Sastra dan Ilmu Sastra. Jakarta: Dunia Pustaka Jaya

[2] Pradopo, Rachmat Djoko. 2002. Kritik Sastra Indonesia Modern. Yogyakarta: Gama Media.

[3] Wellek, Rene dan Austin Warren. 1968. Theory of Literature Harmondsworth, middle-sex: Penguin Books.

[4] Sumardjo, Jakob dan Saini K.M. 1994. Apresiasi Kesusastraan. Jakarta: Gramedia Pustaka Utama.

[5] Echols, John M. Dan Hassan Shadily. 2015. Kamus Inggris Indonesia. Jakarta: Gramedia Pustaka Utama.

[6] Departemen Pendidikan dan Kebudayaan. 1995. Kamus Besar Bahasa Indonesia. Jakarta: Balai Pustaka.

[7] Ismawati, Esti. 2013. Pengajaran Sastra. Yogyakarta: Ombak.

[8] Beach, Richard W. and James D. Marshall. 1991. Teaching Literature in The Secondary School. USA: Harcourt Brace Jovanovich Publishers. 